\title{
Efektifitas Gel Ekstrak Etanol Daun Asam Jawa (Tamarindus indica L.) Terhadap Jumlah Fibroblast Pada Proses Penyembuhan Luka Insisi Tikus Jantan Galur Sprague Dawley
}

\author{
Effectiveness of Gel Extract Ethanolic of Tamarind Leaves (Tamarindus Indica \\ L.) on the Number of Fibroblast in Wound Healing Incision on Sprague Dawley \\ Rats
}

\author{
Agustina Susilowati*, Dian Ratna Rianti, Erma Yunita, Nanda Syta Nur'aini \\ Akademi Farmasi Indonesia, Yogyakarta \\ Corresponding author: Agustina Susilowati: Email: agustinasusilowati@afi.ac.id \\ Submitted: 11-12-2019 \\ Revised: 30-12-2019 \\ Accepted: 30-12-2019
}

\begin{abstract}
ABSTRAK
Obat penyembuhan luka saat ini retalif mahal dan memungkinkan terjadinya efek samping dalam penggunaannya, sehingga perlu dikembangkan obat penyembuhan luka yang berasal dari tanaman herbal. Tanaman herbal yang dapat digunakan sebagai penyembuh luka yaitu tanaman asam jawa (Tamarindus indica). Asam jawa memiliki senyawa flavonoid, saponin, dan tanin yang berfungsi sebagai penyembuhan luka. Tujuan penelitian ini untuk dapat mengetahui efektifitas gel ekstrak etanol daun asam jawa terhadap jumlah fibroblast pada proses penyembuhan luka insisi tikus jantan galur Sprague Dawley. Metode dari penelitian ini yaitu eksperimental dengan menggunakan 25 ekor tikus dan dibagi menjadi 5 kelompok perlakuan dengan masingmasing terdiri dari 5 ekor tikus. Kelompok I (kontrol negatif), kelompok II (kontrol positif, kelompok III, IV dan V diberikan sediaan gel ekstrak etanol daun asam jawa 0,5\%,1\% dan 2\%. Hasil dari penelitian diketahui bahwa gel ekstrak etanol daun asam jawa dengan konsentrasi 0,5\%, 1\% dan 2\% tidak berbeda bermakna ( $\mathrm{p}>0,05)$ dengan kelompok kontrol positif, sehingga dapat disimpulkan bahwa gel ekstrak etanol daun asam jawa konsentrasi 0,5\%, $1 \%$ dan $2 \%$ dapat berperan sebagai penyembuh luka insisi dengan mekanisme meningkatkan jumlah fibroblast.
\end{abstract}

Kata kunci: Luka Insisi; Gel; Ekstrak Etanol; Daun Asam Jawa; Fibroblast

\section{ABSTRACT}

Nowadays wound healing medicines are expensive and allow side effects in their use, so it is necessary to develop wound healing medicines derived from herbal plants. Herbal plants that can be used as a wound healer, namely tamarind plants (Tamarindus indica L.). Tamarind has flavonoid compounds, saponins, and tannins that function as wound healing. The purpose of this study was to determine the effectiveness of the ethanol extract gel of tamarind leaves on the number of fibroblasts in the wound healing process of the Sprague Dawley strain male rat incision. The method of this research is experimental using 25 rat mice and divided into 5 treatment groups with 5 mice each. Group I (negative control), group II (positive control), group III, IV and V were given 0.5\%, 1\% and $2 \%$ ethanolic extract gel of gel. The results of the study found that the ethanol extract gel of tamarind leaves with concentrations of $0.5 \%, 1 \%$, and $2 \%$ were not significantly different ( $p>0.05$ ) from the positive control group, so it can be concluded that the ethanol extract gel of tamarind leaves concentration of $0.5 \%, 1 \%$, and $2 \%$ could play a role as incision wound healing with a mechanism of increasing the number of fibroblasts in the although is still lower than the positive control group.

Keywords: Incision Wound; Gel; Ethanol Extract; Tamarind Leaves; Fibroblast

\section{PENDAHULUAN}

Luka merupakan suatu keadaan terputusnya kontinuitas jaringan tubuh, yang dapat menyebabkan terganggunya fungsi tubuh sehingga dapat mengganggu aktivitas sehari-hari (Damayanti dkk., 2015). Luka dapat diklasifikasikan berdasarkan dua yaitu berdasarkan proses terjadinya luka (mechanism of injury) serta berdasarkan derajat terkontaminasi suatu luka oleh berbagai mikroorganisme (degree of contamination) (Abdurrahmat, 2014). Salah satu jenis luka berdasarkan proses terjadinya luka yaitu luka insisi atau lebih sering dikenal dengan luka iris. Luka insisi atau luka iris merupakan luka yang diakibatkan oleh irisan benda tajam yang menimbulkan kerusakan 
pada pembuluh darah. Penyembuhan luka terdiri dari 3 fase utama yang meliputi fase inflamasi, fase proliferasi serta fase maturasi (Velnar dkk., 2009). Saat kulit mengalami luka, terjadi salah satu proses penyembuhan luka yaitu proses pembentukan granulasi yaitu pembentukan jaringan ikat baru yang terdiri dari sel leukosit, sel fibroblast dan pembentukan pembuluh darah baru (Rubin, 2012).

Obat penyembuhan luka saat ini retalif mahal dan memungkinkan terjadinya efek samping seperti ruam pada kulit. Pengobatan dengan menggunakan tanaman herbal merupakan pengobatan alternatif sebagai penyembuhan luka, karena mudah untuk ditemukan serta tidak menimbulkan adanya efek samping (Suparni dan Ari, 2012). Salah satu tanaman yang termasuk dalam tanaman herbal yaitu tanaman asam jawa. Tanaman asam jawa dapat dimanfaatkan sebagai terapi diare, disentri, antimikroba, ulkus peptik, spaspolitik, dan penyembuhan luka (Kuru, 2014). Bhadoriya dkk. (2015) meneliti bahwa ekstrak metanolik biji asam jawa memiliki aktivitas sebagai antiinflamasi dan analgetik. Penelitian Naik dkk. (2017), gabus dan biji asam jawa menunjukkan adanya aktivitas penyembuhan luka eksisi pada tikus Wistar Albino. Zat aktif yang berperan sebagai penyembuhan luka berupa antiinflamasi yaitu senyawa tanin, saponin dan flavonoid. Senyawa tanin berfungsi sebagai adstringen pada luka, senyawa saponin berperan sebagai meningkatkan kecepatan dalam epitelisasi, serta senyawa flavonoid berperan sebagai penangkal radikal bebas dan oksidasi enzim sebagai antiinflamasi (Soni dan Akhles, 2012).

Penelitian ini bertujuan untuk mengetahui efektifitas gel ekstrak etanol daun asam jawa terhadap jumlah fibroblast pada proses penyembuhan luka insisi tikus jantan galur Sprague Dawley. Ekstrak dibuat dalam bentuksediaan gel karena memudahkan untuk pelepasan zat aktif dibandingkan dengan sediaan krim, pasta, dan salep (Mehta dkk, 2015).

\section{METODOLOGI \\ Bahan}

Daun asam jawa, n-heksan, alkohol 96\%, $\mathrm{HCl}$ pekat, $\mathrm{FeCl} 3$, serbuk $\mathrm{Mg}$, propilenglikol, triatanolamin, metil paraben, Karbopol 940, tikus galur Sprague Dawley, eter, hematoksilin eosin, sekam, pakan tikus, dan kertas saring.
Alat

Alat yang digunakan pada peneliatan ini adalah oven, seperangakat alat maserasi, alatalat gelas, alat-alat bedah, rotary evaporator, kandang tikus, dan alat cukur rambut.

\section{Jalannya Penelitian}

Penyiapan Simplisia

Memanen daun asam jawa serta dilakukan sortasi yang berguna untuk memisahkan daun dengan pengotor, kemudian dilakukan pencucian dengan air mengalir. Daun asam jawa yang telah dicuci dikeringkan dengan diangin-anginkan selama 3 hari. Daun yang telah kering dibuat serbuk dengan cara serbuk daun asam jawa diblender. Penyerbukan ini dilakukan untuk memperkecil ukuran partikel daun asam jawa. Serbuk yang telah diperoleh diayak dengan menggunakan ayakan, kemudian dilanjutkan ke tahap ekstraksi serbuk daun asam jawa (Rianti dkk., 2019).

\section{Ekstraksi}

Ekstraksi serbuk daun asam jawa dilakukan sebanyak 2 tahap. Tahap pertama yaitu maserasi serbuk daun asam jawa menggunakan n-heksan selama 1x24 jam, kemudian dilakukan remaserasi pada residu penyaringan dengan pelarut yang sama sebanyak 2 kali.

Tahap kedua yaitu melakuakan maserasi terhadap residu tahap pertama dengan menggunakan etanol 96\% selama 1x24 jam, serta dilakukan remaserasi dengan etanol $96 \%$ sebanyak 8 kali. Maserat etanol diuapkan menggunakan rotary evaporator dan dipekatkan dengan waterbath hingga diperoleh ekstrak kental daun asam jawa (Rianti dkk., 2019).

\section{Skrining Fitokimia}

Uji Flavonoid

Menambahkan $1 \mathrm{~mL}$ ekstrak etanol daun asam jawa dengan beberapa tetes $\mathrm{HCl}$ pekat, ditambah sedikit serbuk Mg. Adanya flavonoid ditunjukkan dengan terjadinya perubahan warna kuning jingga atau merah (Ikalinus dkk., 2015).

\section{Uji Tanin}

Ekstrak kental daun asam jawa dididihkan dengan $20 \mathrm{~mL}$ air kemudian disaring serta menambahkan beberapa tetes $\mathrm{FeCl}_{3}$. 
Tabel I. Formulasi Gel Ekstrak Etanol Daun Asam Jawa

\begin{tabular}{lccc}
\hline \multirow{2}{*}{ Bahan } & \multicolumn{3}{c}{ Jumlah Bahan (\%) } \\
\cline { 2 - 4 } & F1 & F2 & F3 \\
\hline Ekstrak asam jawa & $0,5 \%$ & $1 \%$ & $2 \%$ \\
Karbopol 940 & 1 & 1 & 1 \\
Trietanolamin & q.s & q.s & q.s \\
Propilenglikol & 7 & 7 & 7 \\
Metil paraben & 0,1 & 0,1 & 0,1 \\
Aquades ad & 100 & 100 & 100 \\
\hline
\end{tabular}

Adanya senyawa tanin ditunjukkan dengan terbentuknya warna hijau kehitaman atau biru tua (Ikalinus dkk., 2015).

\section{Uji Saponin}

Ekstrak kental daun asam jawa dididihkan dengan $20 \mathrm{~mL}$ air. Filtrak dikocok serta didiamkan selama 15 menit. Adanya senyawa saponin ditunjukkan dengan terbentuknya busa yang stabil (Ikalinus dkk., 2015).

Pembuatan Gel Ekstrak Etanol Daun Asam Jawa Pembuatan gel ekstrak etanol daun asam jawa menggunakan formulasi (Tabel I).

Menimbang bahan sesuai dengan masingmasing formula. Melarutkan karbopol, propilenglikol serta metil paraben sesuai dengan perhitungan formula ke dalam aquades (campuran I), gojog hingga larut. Setelah larut campuran I disimpan selama $1 \times 24$ jam pada suhu ruang yang berguna untuk mengoptimalkan proses swelling. Setelah penyimpanan $1 \times 24$ jam, campuran diaduk dengan menggunakan stirer disertai dengan pemanasan. Dari hasil pengadukan dinetralisasi dengan trietanolamin guna untuk mencapai pH 5,05,5, kemudian campuran disimpan kembali pada suhu ruang dalam wadah tertutup selama satu minggu. Melarutkan sebanyak 0,5\%, 1\% dan 2\% ekstrak kental daun asam jawa ke dalam propilenglikol sesuai dengan masing-masing formula serta memasukkan larutan ekstrak ke dalam campuran I sambil diaduk hingga homogen. Adkan gel dengan aquadest hingga bobot mencapai $100 \mathrm{~g}$ sambil diaduk hingga homogen (Susilowati dkk, 2019).

\section{Perlakuan Luka Insisi Pada Tikus}

Penelitian ini telah mendapatkan persetujuan etik dari komite etik penelitian Universitas Ahmad Dahlan dengan nomor 021907008. Dalam penelitian ini menggunakan tikus jantan galur Sprague Dawley berjumlah 25 ekor tikus yang dibagi menjadi 5 kelompok perlakuan. Masing-masing kelompok terdiri dari 5 tikus yaitu: Kelompok I : kontrol negatif (basis gel); Kelompok II : kontrol positif (bioplasenton gel); Kelompok III : gel ekstrak etanol daun asam jawa 0,5\%; Kelompok IV : gel ekstrak etanol daun asam jawa 1\%; Kelompok V : gel ekstrak etanol daun asam jawa $2 \%$.

Sebelum dilakukan pembuatan luka insisi, pada bagian punggung tikus dibersihkan terlebih dahulu menggunakan desinfektan alkohol 70\% dan tikus dianestesi secara inhalasi dengan eter. Bulu tikus pada bagian punggung dicukur menggunakan alat cukur rambut kemudian dibuat luka insisi dengan scalpel sepanjang $2 \mathrm{~cm}$. Luka pada bagian punggung tikus diolesi gel sesuai dengan perlakuan masing-masing kelompok $3 \mathrm{x}$ sehari sebanyak 0,2 gram selama 5 hari berturut-turut (Susilowati dkk, 2019).

Setelah hari ke 5, tikus dinekropsi dengan cara tikus dimasukan ke dalam toples yang telah jenuh oleh eter sehingga terinhalasi oleh tikus sampai kaki dan ekor tikus tidak menunjukan refleksnya saat disentuh atau ditekan. Setelah tikus tidak menunjukkan adanya respon, mengambil bagian kulit yang mengalami perlakuan. Jaringan kulit tersebut kemudian dibuat preparat (HE) dan dilanjutkan dengan pembacaan serta perhitungan jumlah sel fibroblast (Aulia, 2014). Peoses pembacaan jaringan sel fibroblast dilakukan pada jaringan ikat pada area penyembuhan luka dengan menggunakan mikroskop Olympus cx33 dengan perbesaran 400x serta proses perhitungan jumlah sel fibroblast dilakukan dengan menggunakan cell counter pada aplikasi image-J. Masing-masing preparat dilakukan pembacaan setiap lima lapang pandang yang berbeda (Dewi, 2018). Sel fibroblast memiliki inti berbentuk lonjong ketika dipotong dan berwarna ungu pucat (Aulia, 2014). 
Tabel II. Hasil Skrining Fitokimia Ekstrak Etanol Daun Asam Jawa (Susilowati dkk., 2019)

\begin{tabular}{lcl}
\hline \multicolumn{1}{c}{ Pengujian } & Hasil & \multicolumn{1}{c}{ Keterangan } \\
\hline Uji flavonoid & ++ & Terbentuk larutan merah magenta pucat \\
& & dalam waktu 3 menit \\
Uji saponin & +++ & Terbentuk busa stabil \\
Uji tanin & +++ & Terbentuk endapan biru tua \\
\hline
\end{tabular}

Keterangan: $++\quad$ positif; $+++=$ positif kuat

Tabel III. Rata-Rata Jumlah Sel Fibroblast

\begin{tabular}{lc}
\hline \multicolumn{1}{c}{ Kelompok } & Rata-Rata Jumlah Fibroblast \\
\hline Kel I $:$ :kontrol negatif (basis gel) & 569,33 \\
Kel II : kontrol positif (gel Bioplacenton) & $920,00 \mathrm{a}$ \\
Kel III : gel ekstrak etanol daun asam jawa 0,5\% & $890,00 \mathrm{abc}$ \\
Kel IV : gel ekstrak etanol daun asam jawa 1\% & $746,00 \mathrm{abc}$ \\
Kel V : gel ekstrak etanol daun asam jawa 2\% & $908,67 \mathrm{abc}$ \\
\hline
\end{tabular}

$\mathrm{a}=$ berbeda bermakna dengan kontrol negatif $(\mathrm{p}<0,05) ;{ }^{\mathrm{b}}=$ tidak berbeda bermakna dengan kontrol positif $(\mathrm{P}>0,05) ; \mathrm{c}=$ tidak ada perbedaan bermakna antar kelompok perlakuan gel ekstrak etanol daun asam jawa $(\mathrm{P}>0,05)$

\section{Analisis Data}

Hasil dari perhitungan jumlah sel fibroblast antar masing-masing kelompok dianalisis menggunakan bantuan perangkat lunak spss versi 23 dengan taraf kepercayaan $95 \%$.

\section{HASIL DAN PEMBAHASAN}

Hasil dari ekstraksi diperoleh rendemen sebanyak 13,46\% (Susilowati dkk, 2019). Ekstrak ketal yang diperoleh dilakukan uji skrining fitokimia yaitu uji flavonoid saponin, dan tanin. Hasil dari uji skrining fitokima menunjukkan kesesuaian dengan penelitian dari Mun'im dkk. (2009), bahwa ekstrak etanol daun asam jawa mengandung senyawa flavonoid, saponin serta tanin. Hasil data pengujian skrining fitokimia ekstrak etanol daun asam jawa disajikan dalam Tabel II.

Penelitian ini dilakukan dengan tujuan untuk mengetahui efektifitas gel ekstrak etanol daun asam jawa terhadap jumlah fibroblast pada proses penyembuhan luka insisi tikus jantan galur Sprague Dawley. Rata-rata hasil jumlah fibroblast dari masing-masing kelompok disajikan pada Tabel III.

Hasil dari perhitungan jumlah fibroblast dianalisis menggunakan software spss versi 23 yang diuji dengan uji Anova dan dilanjutkan dengan uji LSD. Tujuan dari penelitian ini yaitu untuk mengetahui efektifitas gel ekstrak etanol daun asam jawa terhadap jumlah fibroblast pada proses penyembuhan luka insisi tikus jantan galur Sprague Dawley dengan parameter meningkatnya jumlah fibroblast.

Berdasarkan analisis data yang didapatkan, gel ekstrak etanol daun asam jawa mampu meningkatkan jumlah fibroblast tidak berbeda bermakna dengan kelompok kontrol positif. Hal tersebut menunjukkan bahwa gel ekstrak etanol daun asam jawa dapat berperan sebagai penyembuh luka. Proses penyembuhan luka terdiri dari 3 fase, yaitu fase inflamasi, fase fibroplasi atau sering disebut fase proliferasi serta fase maturasi atau fase reabsorbsi. Sel fibroblast merupakan sel yang mendominasi pada fase proliferasi yang muncul pada hari ketiga setelah terjadinya luka hingga 2 minggu setelah terjadinya luka. Fase proliferasi ditandai dengan adanya pergantian matriks provisional yang didominasi oleh platelet serta makrofag secara bertahap yang akan digantikan oleh migrasi sel fibroblast serta deposisi sintesis matriks ekstraseluler yang bertindak sebagai pengganti jaringan sementara berupa fibrin dan fibronektin (Velnar dkk., 2009).

Selain berfungsi sebagai antiinflamasi, daun asam jawa juga dapat berpengaruh pada penyembuhan luka. Senyawa flavonoid yang terkandung dalam daun asam jawa berperan sebagai antiinflamasi serta berpengaruh dalam proses proliferasi sel fibroblast. Flavonoid mampu 
mengatur fungsi sel inflamasi dengan cara merangsang produksi TGF- $\beta$ sebagai stimulasi makrofag dan bFGF yang dapat menimbulkan pembentukan pembuluh darah endotel pada sekitar area luka dan menginduksi VEGF. VEGF berperan dalam proses pembentukan pembuluh darah baru dalam proses penyembuhan luka (Nofikasari dkk., 2016). Senyawa tanin merupakan polifenol yang dapat menginduksi TGF- $\beta$ serta berperan sebagai antioksidan yang dapat menginduksi TGF- $\beta$ untuk proliferasi sel fibrolast (Khan dkk., 2012). Senyawa tanin juga berperan sebagai astringen pada luka serta senyawa saponin berperan sebagai peningkat kecepatan epitelisasi pada luka (Soni dan Akhles, 2012). Selain berperan sebagai peningkat kecepatan epitelisasi, senyawa saponin berfungsi sebagai immunomodulator, sebagai peningkat produksi dan migrasi makrofag ke daerah luka sehingga dapat meningkatkkan sekresi sitokin IL$1 \beta$ serta dapat meningkatkan proliferasi fibroblas. Senyawa saponin dapat meningkatkan TGF- $\beta$ yang menstimulasi migrasi dan proliferasi fibroblast (Robin, 2007). Oleh sebab itu, senyawa yang terkandung dalam ekstrak daun asam jawa dapat mempercepat dalam proses inflamasi menuju tahap proliferasi sehingga dapat mempercepat proses penyembuhan luka.

\section{KESIMPULAN}

Kombinasi minyak biji nyamplung dan Gel ekstrak etanol daun asam jawa dengan konsentrasi $0,5 \%, 1 \%$ dan $2 \%$ dapat diguEnakan sebagai penyembuh luka insisi dengan mekanisme meningkatkan jumlah fibroblast yang tidak berbeda bermakna dengan kelompok kontrol positif (gel bioplacenton).

\section{UCAPAN TERIMA KASIH}

Penulis mengucapkan terimakasih kepada Kemenristek Dikti yang telah memberikan bantuan dana melalui Hibah Penelitian Dosen Pemula (PDP) tahun anggaran 2019.

\section{DAFTAR PUSTAKA}

Abdurrahmat, A. 2014. Luka, Peradangan dan Pemulihan. Jurnal Enteropi. 10(1): 721-840.

Aulia, Audi F. 2014. Pengaruh Pemberian Salep Ekstrak Daun Binahong (Anredera cordifolia (Tenore) Steenis) Terhadap Pembentukan Jaringan Granulasi Pada Luka Bakar Tikus Sprague Dawley (Studi Pendahuluan Lama
Paparan Luka Bakar 10 Detik Dengan Plat Besi). Skripsi. Jakarta: UIN Syarif Hidayatullah.

Bhadoriya SS., Mishra V., Raut S., Ganeshpurkar A., Jain SK. 2012. Anti-Inflammatory and Antinociceptive Activities of a Hydroethanolic Extract of Tamarindus Indica Leaves. Scientia Pharmaceutica. 80(3):685-700.

Damayanti, I., Risa Pitriani, \& Yulrina Ardhiyanti. 2015. Panduan Lengkap Keterampilan Dasar Kebidanan II. Yogyakarta: Deepublish. 6466.

Dewi, Putu S. 2018. Efektifitas Ekstrak Lidah Buaya Terhadap Jumlah Sel Fibroblast Pada Proses Penyembuhan Luka Incisi Marmut. Jurnal Intisari Sains Medis. 9(3): 51-54.

Ikalinus R., Sri K.W., Ni Luh E.S. 2015. Skrining Fitokimia Ekstrak Etanol Kulit Batang Kelor (Moringa oleifera), Indonesia Medicus Veterinus. 4(1) : 71-79.

Khan, R.A., Muhammad R.K., Sumaira S., Naseer A.S., Jasia B., Umbreen R., and Shumaila J. 2012. Phytotoxic Characterization of Various Fractions Of Launaea Nudicaulis. Journal of Medicinal Plants Research. 6(8): 1403-1406.

Kuru P. 2014. Tamarindus indica and its health related effects. Asian Pacific Journal of Tropical Biomedicine. 4(9):676-681.

Mehta, D.P., Rathod, H.J., Shah, D.P. \& Shah, C.N. 2015. Review on Microemulsion Based Gel: A Recent Approach for Topical Drug Delivery System. Research Journal of Pharmacy and Technology. 8(2): 118-126.

Mun'im, Abdul, Endang H., dan Rahmadiah. 2009. Karakterisasi Ekstrak Etanolik Daun Asam Jawa (Tamarindus Indica L.). Majalah Ilmu Kefarmasian. 6(1): 38 - 44.

Naik, Thejaswi I., Shrikanth P., Ravi M., dan Shridara B.T. 2017. Wound healing activity of Tamarindus indica Linn. seed and cork ash. Journal of Ayurveda Medical Sciences. 2(1): 129-35.

Nofikasari, Icha, Afifah R., Chynintia D.A., Failasofia, Annisa R.F., dan Juni H. 2016. Efek Aplikasi Topikal Gel Ekstrak Pandan Wangi Terhadap Penyembuhan Luka Gingiva. Majalah Kedokteran Gigi Indonesia. 2(2): 53-59.

Rianti, D.R., Erma Y., Agitha D.P., Nanda S.N., Agustina S., 2019. Uji stabilitas gel ekstrak etanol daun asam jawa (Tamarindus indica L.). Jurnal Kefarmasian Akfarindo. 4 (2): 31-35. 
Robbin. 2007. Buku Ajar Patologi Volume 1. Jakarta: EGC.

Rubin, Rhyner S. 2012. Clinicophatologic Foundations of Medicine Sixth Edition. Cina : Lippincott Williams and Wilkins.

Soni, H., \& Akhles S. 2012. A Recent Update of Botanicals For Wound Healing Activity. International Research Journal of Pharmacy. 3(7): 1-7.

Suparni, Ibunda dan Wulandari, Ari. (2012).
Herbal Nusantara: 1001 Ramuan Asli Indonesia. Yogyakarta: ANDI.

Susilowati, A., Dian Ratna R., Erma Y. 2019. Uji Efek Antiinflamasi Gel Ekstrak Etanol Daun Asam Jawa Terhadap Jumlah Neutrofil Pada Tikus Jantan Galur Sprague Dawley, Prosiding Seminar Nasional Kesehatan dalam Safe Cosmetics for Your Healthy Skin: 1-9. Bengkulu, 30 November 2019, Akademi Farmasi AlFatah Bengkulu 